\title{
A radiological study of some ornamental stones: the bluish granites from Extremadura (Spain)
}

\author{
D. Pereira ${ }^{1}$, L. Neves ${ }^{2}$, A. Pereira ${ }^{2}$, M. Peinado ${ }^{1}$, J. A. Blanco ${ }^{1}$, and J. J. Tejado ${ }^{3}$ \\ ${ }^{1}$ Departamento de Geología, Universidad de Salamanca, Spain \\ ${ }^{2}$ IMAR, Dept. Ciências da Terra, Universidade de Coimbra, Portugal \\ ${ }^{3}$ INTROMAC, Cáceres, Spain \\ Correspondence to: D. Pereira (mdp@usal.es)
}

Received: 19 November 2010 - Revised: 19 November 2011 - Accepted: 24 November 2011 - Published: 17 February 2012

\begin{abstract}
In the area of Trujillo (Extremadura, Spain) we have found a variety of striking bluish and secondary yellow granites outcropping within the Plasenzuela pluton. They are all quarried under different names and are characterized by leucocratic minerals in which a bluish phosphate is dispersed throughout the rock. Their physical and mechanical properties make these granites a perfect option for most applications as ornamental rocks. Within the pluton the radiological background is fairly homogeneous, with no significant differences between the gamma ray fluxes of the different facies. $\mathrm{U}(6.4 \pm 0.51 \mathrm{ppm})$, Th $(2.9 \pm 0.47 \mathrm{ppm})$ and $\mathrm{K}_{2} \mathrm{O}$ $(4.32 \pm 0.26 \%)$ contents determined in the laboratory by gamma-ray spectrometry from representative samples are in good accordance with fast in situ measurements carried out with the same technique and also with conventional chemical analysis. Estimated activities for K-40, Ra-226 and Th232 were, on average, $1022 \pm 36 \mathrm{~Bq} \mathrm{~kg}^{-1}, 84 \pm 9 \mathrm{~Bq} \mathrm{~kg}^{-1}$ and $6.8 \pm 1.6 \mathrm{~Bq} \mathrm{~kg}^{-1}$. On the basis of these results, the $I$ index of EU technical document 112 was determined, with an average result of $0.66 \pm 0.03$. This suggests that the rock can be used with no restrictions for all types of construction purposes. Striking differences were observed between the blue facies and the yellow facies in radon exhalation tests from crushed material $\left(0.03 \mathrm{~Bq} \mathrm{~kg}^{-1}\right.$ vs. $\left.0.20 \mathrm{~Bq} \mathrm{~kg}^{-1}\right)$. Since both granites have similar uranium contents $(6.3 \mathrm{ppm}$ and $6.5 \mathrm{ppm}$, respectively), these results can probably be explained in terms of important differences in the mineralogical distribution of this chemical element, radon emanation being enhanced in the yellow facies. However, due to the ordinary use as ornamental stone, the yellow facies does not present a radiological risk in terms of excess effective dose due to internal exposure to radon.
\end{abstract}

\section{Introduction}

Exposure to ionizing radiation resulting from the natural radioactivity of ornamental rocks has been addressed by several authors in different countries (e.g. Tzortzis et al., 2003; Anjos et al., 2005; Xinwei et al., 2006; Ghosh et al., 2008; Chen et al., 2010; Pereira et al., 2011). The relevance of the contribution of such exposure to the total effective dose must be evaluated carefully, and in view of the economic value of the market for natural stone, the results should be presented without triggering unnecessary public alarm. Here we report a study of several granites, quarried at a pluton in Extremadura (Spain) for use as ornamental stone. Our findings agree with the fact that not all granites can be "demonized" as being highly radioactive, as several authors have suggested (e.g. Kitto et al., 2009). There are different kinds of granites and it has to be taken into account both the mineralogy of the granite and quantity that is used in house building (Pavlidou et al., 2006). Our study was carried out in light of European Commission Report 112 through the evaluation of the $I$ index proposed in this report, which is based on the activities of $\mathrm{Ra}$, Th and $\mathrm{K}$, as follows:

$$
I=\frac{\mathrm{CRa}}{300 \mathrm{~Bq} \mathrm{~kg}^{-1}}+\frac{\mathrm{CTh}}{200 \mathrm{~Bq} \mathrm{~kg}^{-1}}+\frac{\mathrm{CK}}{3000 \mathrm{~Bq} \mathrm{~kg}^{-1}}
$$

The $I$ index can help to discern the potential risk of a specific natural stone as building material, as radon exhalation has been revealed as a useful tool to distinguish some radiological heterogeneities within a single outcrop. 


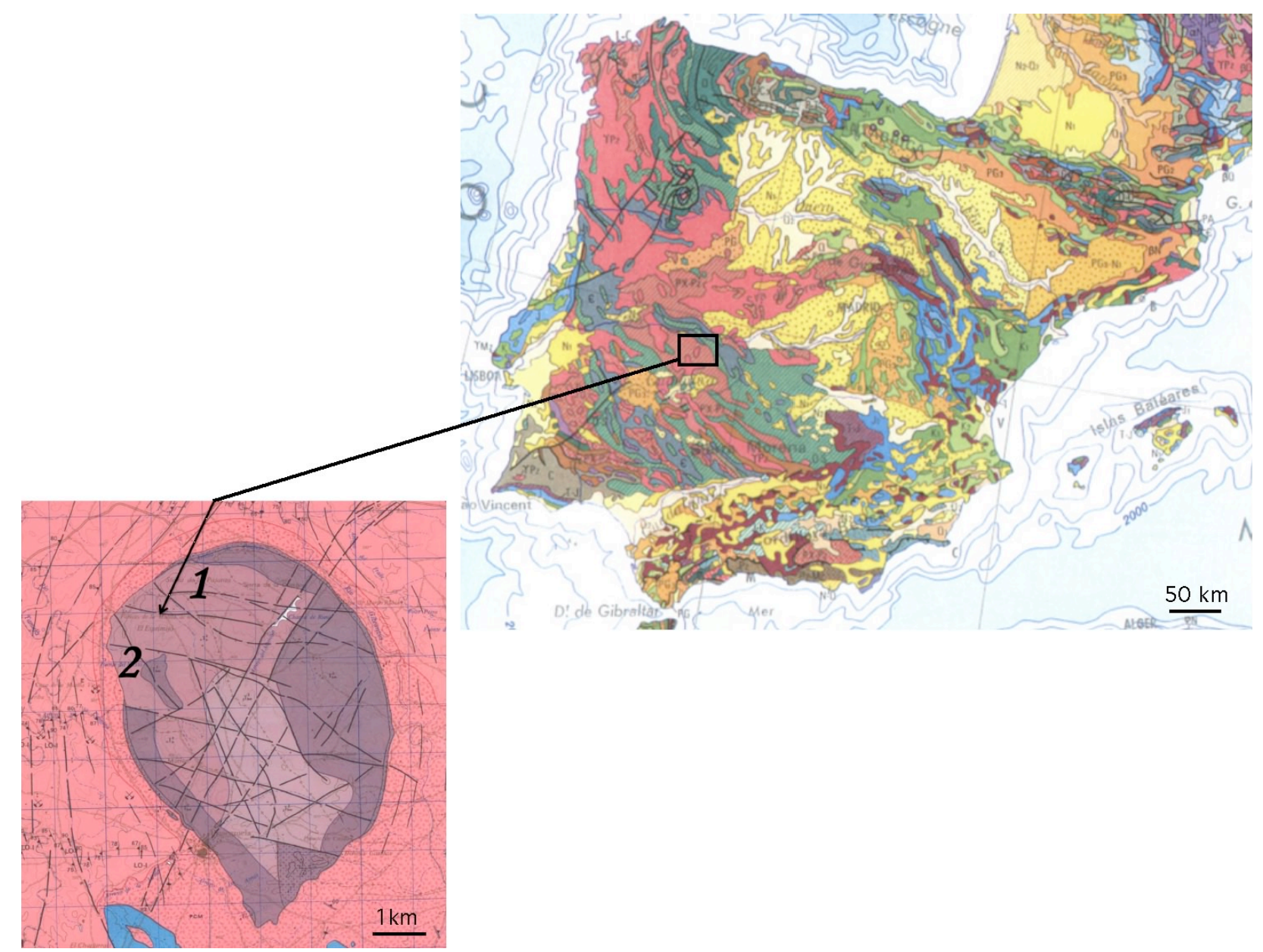

Fig. 1. Location of the Plasenzuela pluton. 1: Azul Platino and Amarillo Platino quarry; 2: Azul Trujillo and Amarillo Trujillo quarry. The map of Plasenzuela pluton is from Montesern and Pérez Rojas (1982). The geological map of Spain is from http://www.iberianature.com/ material/spaingeology.html (last access: 1 November 2011 ).

\section{Geological setting of the bluish granites}

Azul Platino, Azul Trujillo, Violeta Trujillo... These are some of the commercial names used to describe the rocks quarried at Plasenzuela, a granitic pluton intruded around 310 and $330 \mathrm{Ma}$ (Ramírez, 1953, Castro et al., 1999), located in the Variscan belt within the Central Iberia Zone (Spain). More precisely, they are found to the SW of Trujillo (Cáceres), between the localities of Plasenzuela and La Cumbre (Fig. 1). This is one of the late orogenic plutons intruded within the metasediments of the Schist-Greywacke Complex (Pereira and Rodríguez Alonso, 2003, and references therein). The intrusion elicited an important metamorphic aureole in the metasediments, as shown by the neoblastesis of cordierite crystals (Monteserín and Pérez Rojas, 1982). The granite pluton has a clear crustal signature. Within this granite there are different facies, as reflected by grain size, the structures, and the presence or not of potassium feldspar phenocrysts. The pluton has a marginal zone surrounding it made of aplitic granite.
Together with others in the surrounding area, this pluton has been studied for its interest in the mining of metals (Ag, $\mathrm{Pb}, \mathrm{U}$ and $\mathrm{Sn}$; Lago et al, 1989) and ornamental stone, owing to the typical bluish colour of this latter. Hernández Sobrino and Higueras (1991) reported data on fractures and the geotechnical properties of the granite to assess the economic possibilities of mining this rock. These authors suggested that the bluish colour came from quartz, as happens in other bluish granites and volcanic rocks. This is true, but our work has determined that the mineral phase providing the granite with its characteristic colour is a phosphate from the vivianite family.

Fieldwork demonstrated the presence of fresh rocks, called Azul Platino and Azul Trujillo, and weathered rocks, termed Amarillo Platino and Amarillo Trujillo, which seem to represent a superficial layer with a thickness of a few meters in some areas of the pluton. 


\section{Analytical methods}

A field study was carried out with the support of an Exploranium GR130G gamma ray spectrometer, allowing us to recognize heterogeneities in the total gamma fluxes generated by the rocks and also to carry out rapid estimations of their $\mathrm{eK}, \mathrm{eU}$ and eTh contents. Representative samples were taken for the determination of major elements in the granite samples, which was carried out with an Ultima 2 Jobin Yvon optical emission plasma spectrometer at the Chemical Analysis Laboratory of the University of Salamanca. Trace elements by ICP-MS were investigated using acid treatment $\left(\mathrm{HNO}_{3}\right.$ plus $\left.\mathrm{HF}\right)$ under pressure in an Ethos Sel microwave digester from Milestone. The diluted solution was buffered with boric acid, and the same procedure as that used for the water samples was followed. Loss On Ignition (LOI) was calculated by measuring a few grams of powdered rock in a weight-graduated crucible heating it to $950^{\circ} \mathrm{C}$ in an oven, thus allowing water and other volatiles to escape. After cooling in a controlled atmosphere, mass was re-determined and the difference was taken as the LOI value.

$\mathrm{Ra}$, Th and $\mathrm{K}$ values were estimated assuming secular equilibrium in the respective decay chains using a Ortec $\mathrm{NaI}(\mathrm{Tl})$ detector (3 inch) protected from background radiation with a lead shield at the Laboratory of Natural Radioactivity of the University of Coimbra. The samples $(0.5 \mathrm{~kg})$ were prepared at a grain size of less than $0.5 \mathrm{~mm}$, placed in 0.2-1 Marinelli beakers (internal surface area of $0.0219 \mathrm{~m}^{2}$ ), and left for one month to reach equilibrium in the ${ }^{238} \mathrm{U}$ chain before measurements. Counting was performed over $10 \mathrm{~h}$ and the spectra were processed with Scintivison-32 software. The background was evaluated using a Marinelli beaker filled with a radionuclide-free material (pure quartz) under the same analytical conditions, and subsequently subtracted from all samples. Calibration was achieved using standards from the International Atomic Energy Agency: RGK1 (potassium sulphate), RGU-1 (diluted uranium ore) and RGTH-1 (diluted thorium ore) of known composition and activities. K was evaluated from the K-40 peak (1460.8 keV), $\mathrm{Ra}$ from the Bi-214 peak (1764.5 keV), and Th from the Tl208 peak $(2614.5 \mathrm{keV})$, assuming secular equilibrium. Uncertainties are strongly dependent on the radionuclides concentration. Average uncertainties observed in this study were $3.6 \%$ for K-40, $11.5 \%$ for Bi-214 and $36 \%$ for Tl-208.

Radon exhalation was determined from the same prepared samples (previously dried in an oven for $24 \mathrm{~h}$ at $40^{\circ} \mathrm{C}$ ). Samples $(0.5 \mathrm{~kg}$ in weight $)$ were placed inside a $12-1$ capacity radon-proof container made of stainless steel for 4 weeks. The concentration of radon was then measured with an AlphaGuard Pro monitor and the exhalation rate was estimated according to the following equation:
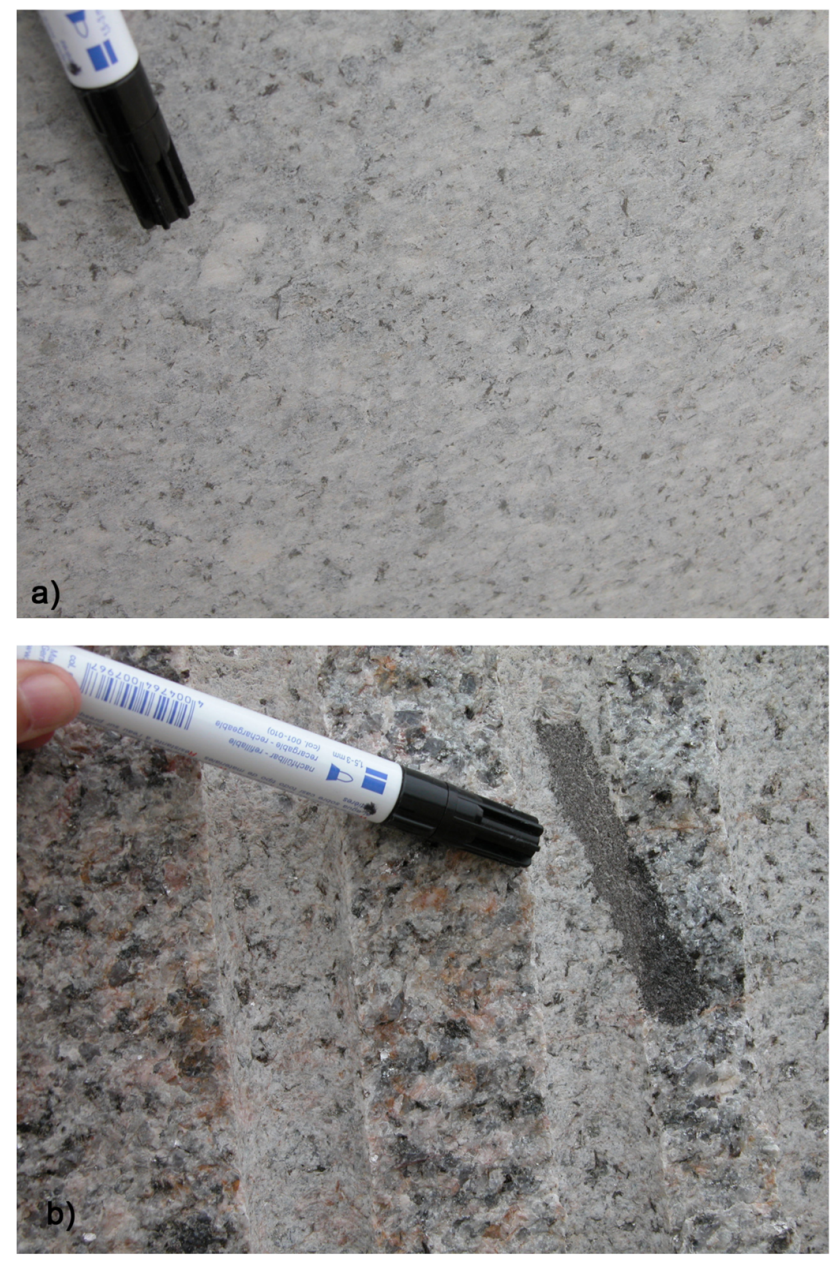

Fig. 2. Mesoscopic aspect of the bluish granites, exhibiting scarce feldspar phenocrysts, (a), and rare micaceous enclaves, (b).

$E_{\mathrm{r}}=\left(\left(C_{\mathrm{r}} V\right) / W\right) \lambda$,

where $E_{\mathrm{r}}$ is the exhalation rate $\left(\mathrm{Bq} \mathrm{kg}^{-1} \mathrm{~h}^{-1}\right) ; C_{\mathrm{r}}$ is the equilibrium radon concentration in the container $\left(\mathrm{Bq} \mathrm{m}^{-3}\right) ; V$ is the free volume of the container (1); $W$ is the weight of the sample $(\mathrm{kg})$, and $\lambda$ is the radon decay constant $\left(\mathrm{h}^{-1}\right)$.

\section{Mineralogy and geochemistry}

In the Plasenzuela area we found a coarse-grained facies, with few orthose phenocrysts (Fig. 2a) and scarce metamorphic enclaves (Fig. 2b). The mineral phases were quartz, Kfeldspar, albite, muscovite, biotite, apatite, tourmaline and zircon. Phosphates were found within and around most of the mineral phases and fillings from stressed structures cutting the rock. We attribute the bluish colour of the granites to this phosphate of the vivianite family. 

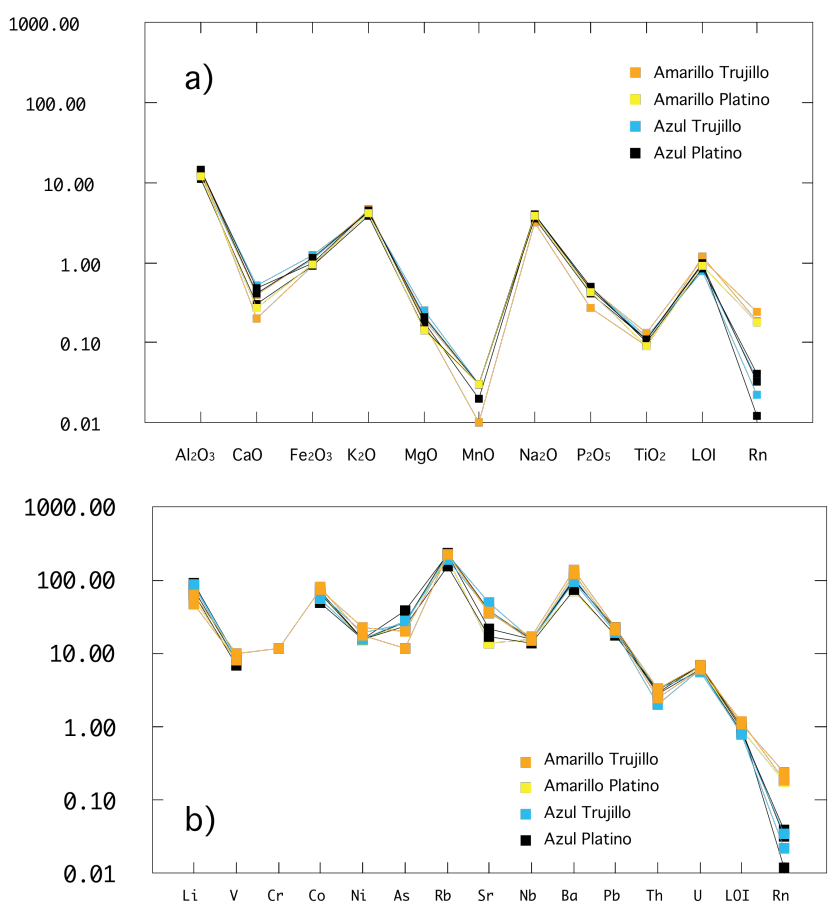

Fig. 3. The largest geochemical difference observed among samples is reflected by the LOI values and Rn exhalation. Major (a) and trace (b) elements have very similar values. Major elements and LOI are expressed in \%; trace elements are expressed in ppm.

Although a geochemical characterization of the granites studied is out of the scope of this work, we did perform a complete geochemical study of the different facies of the commercialized granites from the area; the results will be addressed in a forthcoming work. The present results are projected schematically in Fig. 3, and they show that the rocks have a fairly well developed and homogeneous composition, with high $\mathrm{Rb} / \mathrm{Sr}$ ratios and $\mathrm{P}$ contents, and low $\mathrm{Ca}, \mathrm{K}$ and $\mathrm{Fe}$ contents.

Uranium and thorium levels, as well as the LOI (as an estimate of $\mathrm{H}_{2} \mathrm{O}^{+}$), are shown in Table 2. In agreement with the overall geochemistry, the values shown do not reveal any clear difference between the different facies analysed. The mean values found were $2.9 \mathrm{ppm}$ for Th and $6.4 \mathrm{ppm}$ for $\mathrm{U}$. The most important difference was the content of water and volatiles, which varied between the fresh (Azul Platino and Azul Trujillo) and the weathered rocks (Amarillo Platino and Amarillo Trujillo), where they were systematically higher. LOI is a good quantitative indicator for describing the degree of weathering (Heidari et al., 2010 and references therein). It reflects not only the content of altered minerals, but also the fluids percolating through fractures and impregnating the rock. In our samples, LOI shows a higher degree of weathering in the Amarillo facies (above $1 \%$ in two samples).

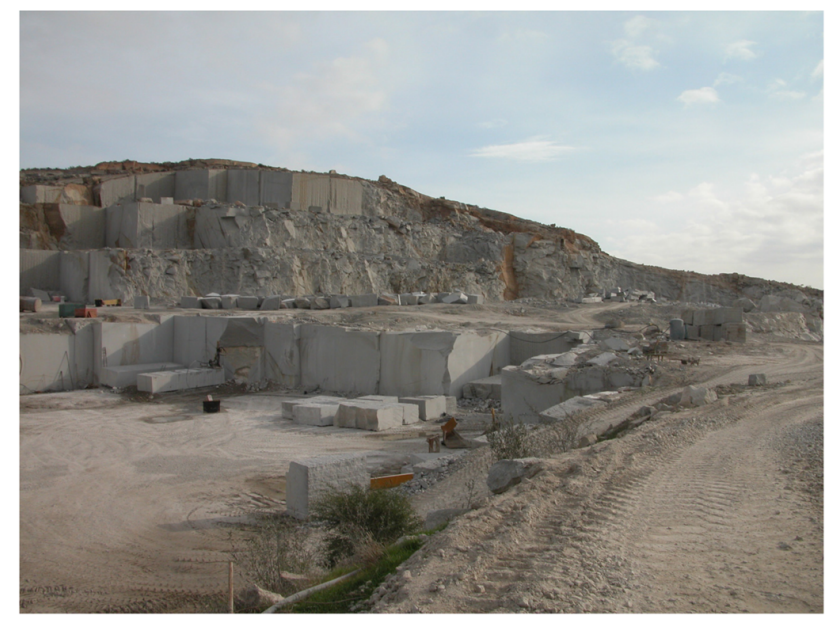

Fig. 4. The Azul Platino and Amarillo Platino quarry. Granite extraction is one of the most profitable activities in Extremadura.

\section{Technical properties}

In Extremadura, the bluish granite facies, named Azul Platino and Azul Trujillo (depending on the quarry where they have been extracted), have been quarried for decades. They respond very well to use as ornamental stone. Their absorption coefficient is somewhat low; their compressive strength values are above the minimum required, and their other technical properties, as seen in Table 1, ensure their excellent behaviour when they are used for such purposes. No alteration due to thermal changes has been observed in the Azul Platino and the Azul Trujillo stone once emplaced in their final use. A secondary yellow facies also occurs in the quarries, spatially close to the topographic surface; it probably represents an alteration product of the original granite (Fig. 4) and it is also commercialized as an ornamental stone, exhibiting the same good technical values. The yellowish facies related to Azul Platino is commercially known as Amarillo Platino. Amarillo Trujillo is the weathered facies related to Azul Trujillo and is the name used here, although it is not commercialized.

\section{Radiological properties}

The radiological background evaluated with a portable gamma ray spectrometer was fairly homogeneous throughout the pluton, with no significant differences between the gamma ray fluxes of the different facies. However, a slight degree of uranium enrichment was observed in some fractures (ca. $15 \%$ above background). The average contents of $\mathrm{U}$, Th and $\mathrm{K}_{2} \mathrm{O}$ estimated in situ with the spectrometer by fast measurements were $7.4 \mathrm{ppm}, 0.8 \mathrm{ppm}$, and $3.67 \%$, respectively $(n=15)$, which is in reasonable accordance with the conventional geochemical analysis reported in Table 2. 
Table 1. Technical properties of two different facies of the bluish granite, Azul Platino and Amarillo Platino (Junta de Extremadura, 2004), and requirements for the use of granite as an ornamental stone (ASTM, 2008).

\begin{tabular}{lrrr}
\hline $\begin{array}{l}\text { Technical } \\
\text { properties }\end{array}$ & $\begin{array}{r}\text { Requirements for granite } \\
\text { as an ornamental stone }\end{array}$ & $\begin{array}{r}\text { AZUL } \\
\text { PLATINO }\end{array}$ & $\begin{array}{r}\text { AMARILLO } \\
\text { PLATINO }\end{array}$ \\
\hline Open porosity $(\%)$ & $(0.4-2.36)^{*}$ & 0.8 & 0.6 \\
Water absorption $(\%)$ & 0.4 & 0.2 & 0.2 \\
Density $\left(\mathrm{kg} \mathrm{m}^{-3}\right)$ & $2.56(2.54-2.66)^{*}$ & 2.65 & 2.67 \\
Resistance to abrasion (mm) & $25(33-88)^{*}$ & 19 & 19 \\
Compressive strength (MPa) & 131 & 160 & 171 \\
Flexural strength (MPa) & 8.27 & 14.4 & 12.8 \\
\hline
\end{tabular}

* Winkler (1997).

Table 2. Chemical and radiological properties of several samples from different facies of the bluish granites. LOI: Loss On Ignition in \%; $\mathrm{K}_{2} \mathrm{O}$ in \%; Th and $\mathrm{U}$ in ppm; $T$ : Rn exhalation. Detection limits were $0.5 \mathrm{ppm}$ for Th, $0.5 \mathrm{ppm}$ for $\mathrm{U}$ and $0.11 \mathrm{ppm}$ for $\mathrm{K}_{2} \mathrm{O}$.

\begin{tabular}{lrrrrr}
\hline Ref. Orig. & $\mathrm{K}_{2} \mathrm{O}$ & $\mathrm{Th}$ & $\mathrm{U}$ & $\mathrm{LOI}$ & $T\left(\mathrm{~Bq} \mathrm{~kg} \mathrm{~h}^{-1}\right)$ \\
\hline AP-1L & 4.39 & 2.9 & 6.9 & 0.94 & 0.03 \\
AP-1L & 3.91 & 3.2 & 6.9 & 0.99 & 0.01 \\
AP-1L & 4.50 & 2.8 & 6.1 & 0.84 & 0.04 \\
AMP-1L & 4.21 & 3.3 & 6.5 & 0.91 & 0.18 \\
AT-2L & 4.11 & 2.0 & 6.1 & 0.79 & 0.02 \\
AT-2L & 4.26 & 3.3 & 5.6 & 0.83 & 0.03 \\
AMT-2L & 4.47 & 3.3 & 7.0 & 1.11 & 0.24 \\
AMT-2L & 4.74 & 2.5 & 6.0 & 1.20 & 0.19 \\
\hline
\end{tabular}

A more precise laboratory analysis using gamma-ray spectrometry allowed us to estimate the activities of K-40, Th232 and Ra-226, assuming equilibrium in the decay chain. The results are shown in Table 2, together with the values of radon exhalation, as determined from the $\mathrm{Rn}-222$ build-up in the containers. $\mathrm{K}_{2} \mathrm{O}$, Th and $\mathrm{U}$ concentrations estimated with this technique are coincident with those obtained by ICP-MS and therefore they are not referred in the table (on average, $3.94 \%$ for $\mathrm{K}_{2} \mathrm{O}$; $6.8 \mathrm{ppm}$ for $\mathrm{U}$, and $1.7 \mathrm{ppm}$ for $\mathrm{Th}$ ). The coincidence of the results obtained by gamma-ray spectrometry and conventional ICP-MS chemical analysis indicates that the $U$ decay series are in secular equilibrium. The contents observed are typical of geochemical well-evolved granites (e.g. Hassan et al., 2011). The uranium contents can be considered as average for this type of lithology.

Using the estimated average activities for K-40 (1022 Bq kg), Ra-226 (83.9 Bq kg) and Th-232 (6.8 Bq kg), the $I$ index of EU technical document 112 was determined, with a result of $0.66 \pm 0.03$ (uncertainty obtained by error propagation of the individual radioisotope measurements). This implies that the rock can be used for building purposes with no restrictions. The estimated excess effective dose for external radiation in the worst-case scenario (used as a

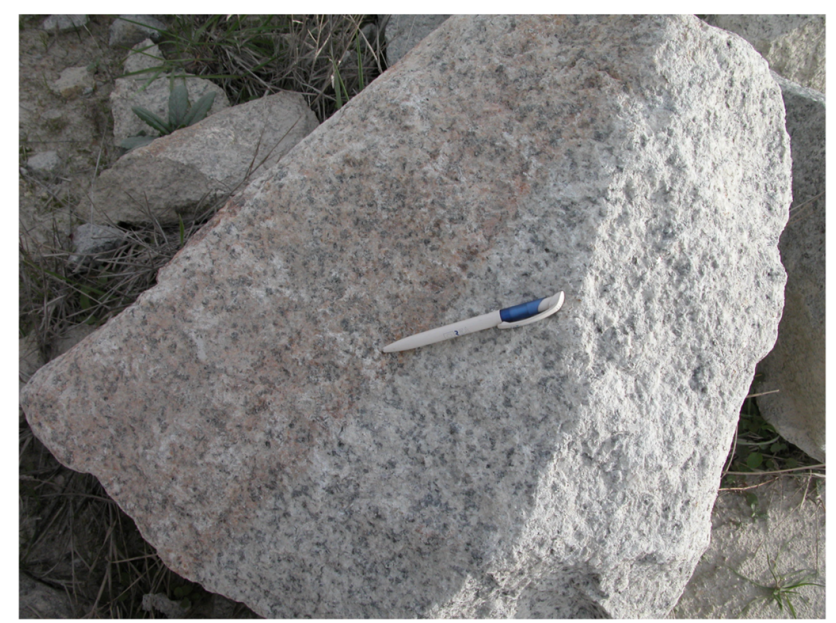

Fig. 5. Azul Platino and Amarillo Platino in the quarry. The latter is the weathered facies of the former.

building material for the whole dwelling) is $0.6 \mathrm{mSv} \mathrm{yr}^{-1}$, thus being negligible when the materials are only used in portions of the house.

However, important differences were observed in the radon exhalation tests carried out in the laboratory facilities. The dominant blue variety had radon exhalation rates ranging between 0.01 and $0.04 \mathrm{~Bq} \mathrm{~kg}^{-1} \mathrm{~h}^{-1}(n=5)$, which are relatively low values for granitic lithologies (Righi and Bruzz 2006, Kitto et al., 2009) and are in good accordance with the estimated uranium contents, while the yellow variety consistently had radon exhalation rates one order of magnitude higher, ranging between 0.18 and $0.24 \mathrm{~Bq} \mathrm{~kg}^{-1} \mathrm{~h}^{-1}(n=3)$ but also in accordance with previous data obtained in similar rocks (Righi and Bruzz, 2006). Since the uranium/radium contents did not differ between the two varieties, these results can only be interpreted in terms of a marked difference in the mineralogical distribution of $\mathrm{U}$, a large proportion of this element not being confined to accessory minerals in the yellow variety as a result of the alteration processes that affected the rock. Moreover, Rn exhalation shows no correlation with any 

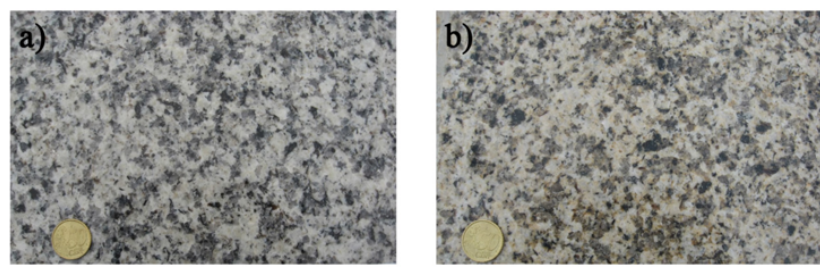

Fig. 6. Polished sections of (a) Azul Platino and (b) Amarillo Platino.

of the chemical elements but correlates with the LOI value ( $r=0.71, p>0.95)$, which can again be interpreted in terms of hydrothermal alteration processes. Hassan et al. (2011) also report a weak correlation between $\mathrm{Rn}$ exhalation and Ra-226 in 15 samples from Europe and Asia.

The results obtained in this work show that for the same excess effective dose of external radiation, as estimated from the $I$ index for both granite varieties, different excess effective doses can be produced for internal radiation, as a result of an enhanced rate of radon release to indoor air in the case of the yellow varieties. EU Report 112 was designed as a screening tool, and clearly states that any decision on restricting the use of a material should be based on a separate dose assessment. In general terms, the results we present suggest that for some radon prone lithologies, namely granites, a dose assessment of the effect of radon release to the indoor air can be useful for a final decision on their use as building materials, especially when there is evidence of high radon exhalation rates not correlated with uranium/radium concentrations. In the case of the granites from Extremadura under study, taking into consideration that they are only used as ornamental stone, which greatly minimizes radon exhalation, it is not expected that the higher values reported for the weathered facies (Amarillo Platino and Amarillo Trujillo) would be sufficient to question the general conclusions obtained from the $I$ index.

\section{Conclusions}

The bluish ornamental granites quarried in Extremadura are present in high amounts and the quarry fronts are the most extensive ones on the Iberian Peninsula. This granite industry is one of the economic bases of the region and we therefore believe that proper characterization regarding the mineralogy, geochemistry and radioactivity of such granites should help in the exploitation of the resources available.

The results of the present study show that the radionuclide contents of the different facies being quarried can be considered normal for granitic lithologies, and the determination of the $I$ index $(0.66 \pm 0.03)$ suggests that these rocks can be used without restriction as building materials and also for ornamental applications. However, the radon exhalation from the weathered yellow facies is higher than that observed for the dominant blue varieties. Taking into consideration the single use as ornamental stone and the low average value of the $I$ index, the increased radon exhalation of this hydrothermally altered variety does not result in a significant increase in the effective dose of radiation. Using a radionuclide analysis protocol has been useful to demonstrate that the radon exhalation value between two somewhat different lithologies can vary significantly even if other radiometric parameters do not notably differ. This is in agreement with what other authors have found out about the correlation between the radon exhalation and the radium content of a particular rock (AlJarallah, 2005; Righi et al., 2006). The next step will be to locate the different $\mathrm{U}$ distribution within the mineral phases.

Acknowledgements. Projects SA110A09, CGL2006-05128/BTE and CGL2010-18579/BTE funded this research. Leticia Rodríguez is acknowledged for helping with the granite sampling and the mineral separation and Nic Skinner for his help with the English grammar. An anonymous reviewer helped to improve the original manuscript and Heiko Woith did an extraordinary revision for which is greatly acknowledged.

Edited by: G. Gillmore

Reviewed by: H. Woith and two other anonymous referees

\section{References}

Al-Jarallah, M. I.: Correlation between radon exhalation and radium content in granite samples used as construction material in Saudi Arabia, Radiat. Meas., 40, 625-629, 2005.

American Society for Testing and Materials: ASTM (C615-03) Standard specification for granite dimension stone, 2008.

Anjos, R. M., Veiga, R., Soares, T., Santos, A. M. A., Aguiar, J. G., Frasc, M. H. B. O., Brage, J. A. P., Uzda, D., Mangia, L., Facure, A., Mosquera, B., Carvalho, C., and Gomes, P. R. S.: Natural radionuclide distribution in Brazilian commercial granites, Radiat. Meas., 39-3, 245-253, 2005.

Castro, A., Patiño Douce, A., Corretgé, G., de la Rosa, J., El-Biad, M., and El-Hmidi, H.: Origin of peraluminous granites and granodiorites, Iberian massif, Spain: an experimental test of granite petrogenesis, Contrib. Mineral Petr., 135, 255-276, 1999.

Chen, J., Rahman, N. M., and Atiya, I. A.: Radon exhalation from building materials for decorative use, J. Environ. Radioactiv., 101-4, 317-322, 2010.

European Commission: Radiation Protection 112 "Radiological protection principles concerning the natural radiactivity of building materials", Luxembourg: Office for Official Publications of the European Communities, ISBN 92-828-8376-0, 1999.

Ghosh, D., Deb, A., Bera, S., Sengupta, R., and Patra, K. K.: Assessment of alpha activity of building materials commonly used in west Bengal, India, J. Environ. Radioactiv., 99-2, 316-321, 2008.

Hassan, N. M., Ishikawa, T., Hosoda, M., Iwaoka, K., Sorimachi, A., Sahoo, S. K., Janik, M., Kranrod, C., Yonehara, H., Fukushi, M., and Tokonami, S.: The effect of water content on the radon emanation coefficient for some building materials used in Japan, Radiat. Meas., 46, 232-237, 2011. 
Lago, A., Castroviejo, R., and Nodal, T.: Las mineralizaciones argentíferas de Plasenzuela, Cáceres, España, Boletín Geológico y Minero, 100, 1059-1074, 1989 (in Spanish).

Hernández-Sobrino, A. and Higueras, P.: Una nueva variedad de granito ornamental: el Violeta Trujillo, RocMaquina, 31-35, 1991 (in Spanish).

Heidari, M., Khanlari, G. R., and Momeni, A. A.: Weathering indices and its relation to uniaxial compressive strength of Hamedan Hololeucogranite rocks in West of Iran, World Appl. Sci. J., 11-2, 142-150, 2010.

Junta de Extremadura, Consejería de Economía y Trabajo, Atlas de las Rocas Ornamentales de Extremadura, 2004.

Kitto, M. E., Haines, D. K., and Arauzo, H. D.: Emanation of radon from household granite, Health Phys., 96, 477-482, 2009.

Monteserín, V. and Pérez-Rojas, A.: Map Sheet no 705 (Trujillo), 1982.

Pavlidou, S., Koroneos, A., Papastefanou, C., Christofides, G., Stoulos, S., and Vavelides, M.: Natural radioactivity of granites used as building materials, J. Environ. Radioactiv., 89, 48-60, 2006.
Pereira, D. and Rodríguez-Alonso, D.: Duality of cordierite granites related to melt-restite segregation in the Peña Negra Anatectic Complex, central Spain, Can. Mineral., 38, 1329-1346, 2000.

Pereira, D., Neves, L., Pereira, A., and Neila, C.: Natural radioactivity in ornamental stones: an approach for its study in known samples from Iberia, B. Eng. Geol. Environ., 70, 543-547, 2011.

Ramírez, E.: El batolito granítico de Plasenzuela (Cáceres), Boletín de la Real Sociedad Española de Historia Natural, Sección Geológica, 51, 35-57, 1953 (in Spanish).

Righi, S. and Bruzzi, L.: Natural radioactivity and radon exhalation in building materials used in Italian dwellings, J. Environ. Radioactiv., 88, 158-170, 2006.

Tzortzis, M., Tsertos, H., Christofides, S., and Christodoulides, G.: Gamma radiation measurements and dose rates in commerciallyused natural tiling rocks (granites), J. Environ. Radioactiv., 70-3, 223-235, 2003.

Winkler, E. M.: Stone in architecture: properties, durability, Ed. Springer, Berlin, 313 pp., 1997.

Xinwei, L., Lingqing, W., and Xiaodan, J.: Radiometric analysis of Chinese commercial granites, J. Radioanal. Nucl. Ch., 267-3, 669-673, 2006. 